\title{
The Significant and Profound Impacts of Chou's Distorted Key Theory for Developing Peptide Drugs
}

\author{
Kuo-Chen Chou \\ Gordon Life Science Institute, Boston, MA, USA
}

Correspondence to: Kuo-Chen Chou, kcchou@gordonlifescience.org, kcchou38@gmail.com

Keywords: AIDS, Peptide Drugs, Distorted Key Theory, Microenvironment

Received: September 1, $2020 \quad$ Accepted: September 7, $2020 \quad$ Published: September 10, 2020

Copyright (c) 2020 by author(s) and Scientific Research Publishing Inc.

This work is licensed under the Creative Commons Attribution International License (CC BY 4.0).

http://creativecommons.org/licenses/by/4.0/

(c) (i) Open Access

\section{ABSTRACT}

In this short review paper, the significant and profound impacts of the distorted key theory for developing peptide drugs have been briefly recalled with crystal clear convincingness.

As a culprit of AIDS [1], HIV protease has been a target for developing drugs against AIDS [2]. Functioning as a dimmer of two identical subunits, HIV protease has a crab-like shape. Its catalytic cleft is gated by a pair of flaps (or pincers if viewed as a crab). When the enzyme is in an inhibitor-free state, the pincer-gate is open, allowing substrates to enter the catalytic cleft; when in an inhibitor-binding state, the pincer-gate is closed, blocking the entrance [3]. As a member of the aspartyl proteases, HIV protease is highly substrate-selective and cleavage-specific. Its susceptible sites in a protein extend to an octapeptide region [4].

Knowledge of the protein cleavage sites by HIV protease can provide very useful information for finding effective inhibitors against the culprit enzyme, as elaborated by Kuo-Chen Chou in [5].

According to Fisher's lock-and-key model proposed by Hermann Emil Fischer in 1984 and Koshland's induced fit theory by Daniel E. Koshland, Jr. in 1958, given a peptide, the prerequisite condition for it to be cleaved by HIV-protease is a good fit and binding between the substrate and the enzyme's active site. However, such a peptide, after a modification on its scissile bond with some simple chemical procedure, will completely lose its cleavability but it can still tightly bind to the enzyme's active site. According to Kuo-Chen Chou [3], the molecule thus modified can be likened to a "distorted key", which can be inserted into a lock but can neither open the lock nor automatically get out from it. That is why a molecule modified from a cleavable peptide can spontaneously become a competitive inhibitor against the enzyme $[6]$.

Even for non-peptide inhibitors, the information derived from the cleavable peptides can also provide useful insights about the key binding groups and fitting conformation, among many other detailed requirements in microenvironment.

Many efforts have been made to predict the protein cleavage sites by HIV-protease (see, e.g., [6-8]). Also, a webserver named HIVcleave was established [9] for predicting HIV protease cleavage sites in proteins. 
Furthermore, Chou's distorted key theory was also utilized to develop inhibitors against severe acute respiratory syndrome (SARS) (see, e.g., [10-12]).

\section{CONFLICTS OF INTEREST}

The author declares no conflicts of interest regarding the publication of this paper.

\section{REFERENCES}

1. Barre-Sinoussi, F., Chermann, J.C., Rey, F., Nugeyre, M.T., Chamaret, S., Gruest, J., Dauguet, C., Axler-Blin, C., Vezinet-Brun, F., Rouzioux, C., Rozenbaum, W. and Montagnier, L. (1983) Isolation of a T-Lymphotropic Retrovirus from a Patient at Risk for Acquired Immune Deficiency Syndrome (AIDS). Science, 220, 868-871. https://doi.org/10.1126/science.6189183

2. Meek, T.D., Lambert, D.M., Dreyer, G.B., Carr, T.J., Tomaszek Jr., T.A., Moore, M.L., Strickler, J.E., Debouck, C., Hyland, L.J., Matthews, T.J., et al. (1990) Inhibition of HIV-1 Protease in Infected T-Lymphocytes by Synthetic Peptide Analogues. Nature, 343, 90-92. https://doi.org/10.1038/343090a0

3. Chou, K.C. (1993) A Vectorized Sequence-Coupling Model for Predicting HIV Protease Cleavage Sites in Proteins. The Journal of Biological Chemistry, 268, 16938-16948.

4. Miller, M., Schneider, J., Sathyanarayana, B.K., Toth, M.V., Marshall, G.R., Clawson, L., Selk, L., Kent, S.B. and Wlodawer, A. (1989) Structure of Complex of Synthetic HIV-1 Protease with a Substrate-Based Inhibitor at 2.3 A Resolution. Science, 246, 1149-1152. https://doi.org/10.1126/science.2686029

5. Chou, K.C. (1996) Review: Prediction of Human Immunodeficiency Virus Protease Cleavage Sites in Proteins. Analytical Biochemistry, 233, 1-14. https://doi.org/10.1006/abio.1996.0001

6. Chou, K.C., Tomasselli, A.L., Reardon, I.M. and Heinrikson, R.L. (1996) Predicting HIV Protease Cleavage Sites in Proteins by a Discriminant Function Method. Proteins. Structure, Function and Genetics, 24, 51-72. https://doi.org/10.1002/(SICI) 1097-0134(199601)24:1<51::AID-PROT4>3.0.CO;2-R

7. Chou, J.J. (1993) Predicting Cleavability of Peptide Sequences by HIV Protease via Correlation-Angle Approach. Journal of Protein Chemistry, 12, 291-302. https://doi.org/10.1007/BF01028191

8. Liang, G.Z. and Li, S.Z. (2007) A New Sequence Representation as Applied in Better Specificity Elucidation for Human Immunodeficiency Virus Type 1 Protease. Biopolymers, 88, 401-412. https://doi.org/10.1002/bip.20669

9. Shen, H.B. and Chou, K.C. (2008) HIVcleave: A Web-Server for Predicting HIV Protease Cleavage Sites in Proteins. Analytical Biochemistry, 375, 388-390. https://doi.org/10.1016/j.ab.2008.01.012

10. Gan, Y.R., Huang, H., Huang, Y.D., Rao, C.M., Zhao, Y., Liu, J.S., Wu, L. and Wei, D.Q. (2006) Synthesis and Activity of an Octapeptide Inhibitor Designed for SARS Coronavirus Main Proteinase. Peptides, 27, 622-625. https://doi.org/10.1016/j.peptides.2005.09.006

11. Du, Q.S., Wang, S.Q., Jiang, Z.Q., Gao, W.N., Li, Y.D., Wei, D.Q. and Chou, K.C. (2005) Application of Bioinformatics in Search for Cleavable Peptides of SARS-CoV Mpro and Chemical Modification of Octapeptides. Medicinal Chemistry, 1, 209-213. https://doi.org/10.2174/1573406053765468

12. Du, Q.S., Sun, H. and Chou, K.C. (2007) Inhibitor Design for SARS Coronavirus Main Protease Based on "Distorted Key Theory". Medicinal Chemistry, 3, 1-6. https://doi.org/10.2174/157340607779317616 